\title{
İzleyici ve İçerik Etkileşimi Bağlamında Yeni Bir YouTube Fenomeni Olarak Otonom Duyusal Meridyen Tepki (ASMR) Etkisinin Deri İletkenliği Ölçümü (GSR) Tekniği ile İncelenmesi
}

\author{
DOI: 10.26466/opus.533789 \\ *
}

Behiç Alp Aytekin $^{*}$

*Dr. Öğr. Üyesi, Aydın Adnan Menderes Üniversitesi, İletişim Fakültesi, Merkez / Aydın / Türkiye E-Posta: alpaytekin@adu.edu.tr

ORCID: $\underline{0000-0001-9121-6445}$

Öz

Dünyanın en popüler video paylaşım platformu Youtube'da günümüz itibariyle yaklaşık 5.2 milyon otonom duyusal meridyen tepki (ASMR) videosu bulunmaktadır. ASMR videoları kullanıcılar tarafindan uzun saatler boyunca ve seriler halinde izlenmekte, hatta sadece bu tarz videolardan oluşan özel ASMR Youtube kanalları yer almaktadır. Bu içeriklerin Youtube üzerinde neden bu kadar popüler olduğu sorusu gündeme geldiğinde ise ASMR videolarının çoğu durumda kullanıcların kaygı düzeylerini azaltma ve izleyicisini rahatlatması yönünde psikolojik çıktılarının olduğunu bulgulayan bilimsel araştırmalar gündeme gelmektedir. ASMR içeriklerinin Youtube iletişim kanalından çıkarak profesyonel medya içerik üretimi ekosistemine dâhil olması, konunun psikolojik boyut ve çıktılarının yanı sıra, medya ve iletişim çalışmaları bağlamında da tartışılması gerekliliğini ortaya koymaktadır. Bu çerçevede Youtube'da yer alan popüler ASMR videolarından ve ASMR tekniği ile prodüksiyonu yapılmış reklamlardan oluşan seçili bir içerik katılımcilara sunulmuştur (n=10). Metodoloji dâhilinde katıllmcilardan elektrodermal (GSR) ve kalp hacim (PPG) verileri nicel olarak toplanmış; aynı zamanda gözlem ve derinlemesine görüşme yöntemleri ile de nicel çıktılar desteklenmiştir. Araştırmadan elde edilen sonuçlar bağlamında, içerikleri deneyimleyenlerden motivasyonel anlamda rahatlayanlar kadar, görüntülerden çeşitli değişkenler doğrultusunda rahatsız olanların da varlığı gözlemlenmiştir. Bu motivasyonel değgişimlerin, gösterilen içerik üzerinden marka, ürün veya hizmet ile ilgili nasıl bir iletişim ve etkileşim çıktısı sağladığı da tespit edilmiştir. Medya ve iletişim çalışmaları literatüründe ASMR içeriklerinin etkilerine yönelik sonuçlara böyle bir karma metodoloji ile bakılmamış olması, araştırmanın orijinal yönü olarak dikkat çekmektedir. Bu araştırmadan elde edilen sonuçların, ASMR içerikleri üzerinden medya ve iletişim literatürü bağlamında gerçekleştirilebilecek teorik ve uygulama temelli çalışmalara zemin oluşturabileceği düşünülmektedir.

Anahtar Kelimeler: Deri İletkenliği Ölçümü (EDR, GSR), Duyusal Marka Deneyimi, Misofonya, Seyir Deneyimi, Sinestezi, Otonom Duyusal Meridyen Tepki (ASMR), YouTube 


\title{
Investigation of the Effect of Autonomous Sensory Meridian Response (ASMR) as a New YouTube Phenomenon in the Context of Audience and Content Interaction with Galvanic Skin Response (GSR) Measurement Technique \\ *
}

\begin{abstract}
There are approximately 5.2 million autonomous sensory meridian response (ASMR) videos on YouTube which the world's most popular video sharing platform. Users watch ASMR videos for long hours and in series, and there are even individual ASMR YouTube channels consisting of such videos. When the question is coming up of why these contents are so popular on YouTube, scientific researches revealing that ASMR videos have psychological outputs in most cases to reduce the anxiety levels of the users and to relieve the audience. The inclusion of ASMR content in the professional media content production ecosystem by opting out of the YouTube communication channel created the need to discuss the context of media and communication studies as well as the psychological dimensions and outcomes of the issue. In this context, selected content consisting of popular ASMR videos on YouTube and produced advertisements with ASMR technique was presented to the participants ( $n=10)$. Electrodermal (GSR) and heart-volume (PPG) data were quantitatively collected from the participants. At the same time, quantitative outputs were supported with observation and in-depth interview methods. In the context of the results obtained from the study, as well as those who are relieved in terms of motivation from those who experience the contents, the presence of those who are disturbed in the direction of various variables have been observed. It has also been determined how these motivational changes provide communication and interaction output related to brand, product or service through the content shown. The fact that the results regarding the effects of ASMR contents in the media and communication studies literature have not been examined with such a mixed methodology is noteworthy as the original aspect of the research. It is thought that the results obtained from this research can be the basis of theoretical and practical studies which can be realized in the context of media and communication literature via ASMR contents.
\end{abstract}

Keywords: Autonomous sensory meridian response (ASMR), Electrodermal Response (EDR, GSR), Misophonia, Sensory Brand Experience, Synesthesia, Watching Experience, YouTube

OPUS (c) Uluslararası Toplum Araştırmaları Dergisi-International Journal of Society Researches ISSN:2528-9527 E-ISSN : 2528-9535

http://opusjournal.net 


\section{Giriş}

Günümüz medya içeriklerinin muhatapları, çok uzun zamandır sadece izleyici olarak tek yönlü ve pasif bir iletişim süreci geçirmek yerine, çeşitli etkileşim aksiyonları alarak, seyirlik çift yönlü sürece katılan birer kullanıcı olarak tanımlanmaktadır. Kullanıcıların görsel ve işitsel içeriklere ulaştığı iletişim kanalları bazında televizyon hala önemli bir etki ve popülerlik alanını doldurmasına rağmen (Tran, 2017), özellikle kullanıcı etkileşimi ve oyunlaştırma süreçlerinin benimsendiği çevrimiçi video paylaşım siteleri, günlük milyonlarca saat içerik akışının takip edildiği ve paylaşıldığı yeni bir iletişim kanalı olarak medyadaki alan hâkimiyetini tartışmasız bir konuma getirmiştir. İçerik paylaşım sitelerinin en büyük temsilcisi olan Youtube, günümüzde yaklaşık 1 milyar saat gibi günlük video paylaşımı ve 63 milyon günlük aktif ziyaretçi rakamı ile çok ciddi bir görselişitsel içeriği bu bağlamda yönetmektedir (Dogtiev, 2019). Öyle ki Youtube üzerinde kısa sürede popüler olan bir içerik ve burada yer alan bir aksiyon, meydan okuma (challange) olarak tabir edilen toplumsal hareketlere dönüşmekte ve uzun süre kamuoyunda tartışılmaya devam etmektedir. Bu meydan okumaların yarattığı toplumsal etkiyi anlamak adına, ALS hastalığı ile mücadele bağlamında farkındalık yaratmak için oluşturulan, 17 milyon insanın meydan okumaya katılarak, toplamda 115 milyon dolar (yaklaşık 610 milyon Türk lirası) yardım toplanmasını sağladığ1 "Ice Bucket Challange" örneğini incelemek yararlı görünmektedir (Trejos, 2017). Üstelik Youtube'da yer alan bu popüler aksiyonların toplumsal olarak bulduğu karşılık, çeşitli kültürel ve dil yaklaşım ve farkl1lıklarını çok kısa sürede aşabilmekte ve uluslararası düzeyde fenomenleşen hareketlere dönüşerek şimdiye kadar modern toplumlarda gözlemlenen en yaygın ve hızlı söylem, propaganda ve moda hareketlerini oluşturmaktadır. Bu tarz fenomen akımları ve meydan okumaları yakalamayı başaran kurumların, profesyonel olarak yürüttükleri medya ve iletişim süreçleri dahilinde bu popüler yönelimleri kendi kurumsal veya marka ç1karları doğrultusunda kullandıkları da bilinmektedir. Özellikle profesyonel reklam endüstrisinin üretim çarkları arasına dahil olan bu yeni görselişitsel içerik üretimi biçimi (çoğu zaman viral reklam olarak karşımıza çımaktadır), aynı zamanda medya kullanımının yeni doğası gereği sun- 
duğu kullanıcı etkileşimi aksiyonlarının da sağladığı katma değer ile temsil ettiği kurum, fikir veya hizmete yönelik çıtının hızlı ve yüksek katılımlı olmasını da sağlamaktadır.

Tüm bu çerçeve dâhilinde, BBC News Türkçe'nin (2019) haberine göre, son dönemlerde Youtube' da yer alan yaklaşık 5.2 milyon içerik ile otonom duyusal meridyen tepki (ASMR) videosu, bahsi geçen popüler içerik alanlarından biri olarak dikkat çekmekte ve bu içerikler Youtube'un yeni trendi olarak görülmektedir. Youtube'da popülerliğini arttıran bu içerik türünün, 2018 yılı dünya genelindeki Google arama yönelimlerinde de yükselişte olduğu görülmektedir.

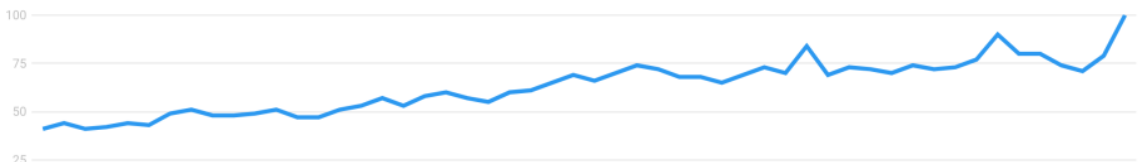

Şekil 1. Google Trends 2018 ASMR Arama Terimi Raporu

Kaynak: Google Trends (https://trends.google.com.tr/trends/explore?q=asmr)

Erişim tarihi: 11.02.2019

Google anahtar kelime bazlı arama trendleri ölçeğindeki 100 değeri, arama teriminin en yüksek popülerliğe sahip olduğu durumu temsil etmektedir (Trends, 2019). Bu bilgi üzerinden, ASMR ile ilgili yükselen içerik talebinin 2019 yılı itibari ile en yüksek popülerlik çizgisine eriştiği ve profesyonel reklamcılık ekosisteminin de bu duruma kayıtsız kalmadığı görülmektedir. Amerika' daki en büyük reklam organizasyonlarına sahne olan Amerikan futbolu şampiyonluk karşılaşmasının (Super Bowl 2019) canlı yayını arasında yer alan reklam kuşağında, ASMR tekniği ile prodüksiyonu gerçekleştirilmiş bir reklam filmine yer verildiği görülmektedir (Johnson, 2019). Böylelikle çevrimiçi adına büyük bir trend olan ASMR'nin, ana akım medyada da oldukça hatırı sayılır bir yer aldığı gözlemlenmektedir. 
Super Bowl organizasyonunun reklam kuşağı, dünyadaki en pahalı medya satın alma rakamlarına sahip olan reklam kuşaklarından biri olarak bilinmektedir. Bu çerçevede Super Bowl'da yer alacak 30 saniyelik bir reklamın kuşak maliyeti 2019 yılı itibariyle 5.25 milyon dolara (yaklaşık 30 milyon Türk lirası) ulaşmaktadır (Statista, 2019).

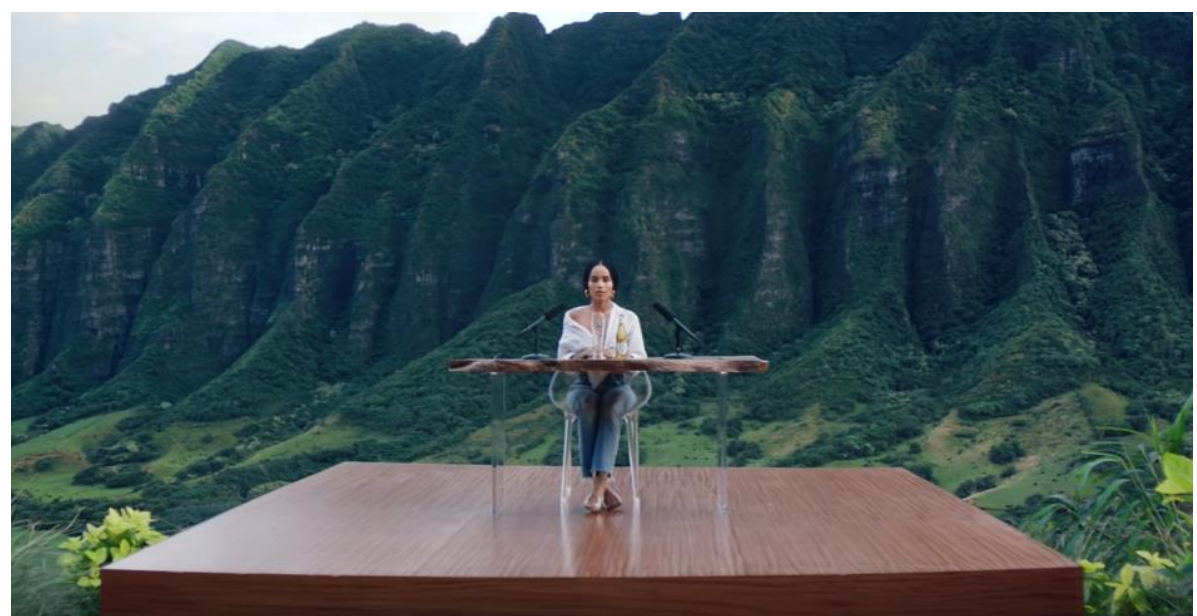

Şekil 2. The Pure Experience, Michelob ULTRA Pure Gold Super Bowl 2019 Reklamı Kaynak: Youtube (https://www.youtube.com/watch?v=LXmlN9BAddg)

Erişim tarihi: 11.02.2019

Super Bowl 2019 reklam kuşağında yer alan Michelob Ultra adlı markanın reklamında ASMR tekniğinin temel özelliklerinden olan fısıldayarak konuşma, yüksek kaliteli olarak kayıt altına alınmış nesne sesleri, tıkırdama, yudumlama, yakın plan çekimler, yüksek kaliteli görsel yakalama tekniği ile ürün dokusunun belirginleştirilmesi gibi tüm bileşenlerin bir arada kullanıldığı görülmektedir. Üstelik uzun süredir bilinen bu tekniğin çoğu izleyicisini rahatlatması ve sakinleştirmesine rağmen, her tetikleyicinin tüm kullanıcılar için uygun olmadığı ve kimi izleyiciyi-kullanıcıyı rahatsız ettiği, ürküttüğü noktaların bulunduğu da bilinmektedir (Maxouris, 2019; Richard, 2017). Bu bilgiye rağmen, tamamen ASMR tekniği ile üretilmiş olduğu görülen Michelob Ultra markasına ait reklamın, dünyanın en pahalı ana akım reklam kuşağına böyle bir prodüksiyon tekniği ile girmesi, profesyonel medya içerik üretimi adına oldukça dikkat çekici bir nokta olarak gündeme gelmektedir. Bu bağlamda izleyicisine 
garip gelen ve sosyal medyada bu ilk ve yeni seyirlik deneyim nedeniyle çoğunlukla olumsuz olarak eleştirilen reklam; Youtube'a yüklendiği tarih olan 28 Ocak 2019'dan bu yana 13 milyon görüntüleme almış; Twitter' da ise 4 bin 200 kez kendisinden bahsettirerek, marka hakkında dakikada 750 Tweet'e kadar ulaşan bir iletişim trafiği yaratmayı başarmıştır (İçözü, 2019). Bu tarz bir tüketici-marka, kullanıcı-içerik etkileşimi ve seyirlik deneyim, şimdiye kadarki içerik akışlarından farklı olarak medya ve iletişim çalışmaları çerçevesi adına yüksek kapasiteli bir verimi ve popüler içerik olan ne sorusunun yanitını vadetmektedir.

ASMR tekniğinin yarattığı etkinin, Youtube platformundan çıkarak, Super Bowl 2019 gibi bir organizasyonun reklam kuşağına girecek kadar büyük bir alana sıçraması ve ASMR etkisinin marka bağlılığı ve itibarı bağlamında izleyici üzerindeki ağırlıklı olumlu etkisine reklam verenler tarafından güvenle bağlanılması, bu tekniğin yeni bir metodolojik yönelim ile medya ve iletişim çalışmaları bağlamında detaylı olarak gözlemlenmesi gerekliliğini ortaya koymaktadır. Bu noktada araştırma sorusu olarak ASMR tekniğinin bahsedilen rahatlama, kaygı giderme, olumlu anlamda etkileme ve sunulan seyirlik odağa dikkati toplama etkilerinin, profesyonel medya ve iletişim içeriği üretimi bağlamında ne kadar kullanışlı olduğu konusu tartışmaya açılmaktadır. ASMR'nin yarattığı etki seçili video içerikler üzerinden nicel ve nitel olarak bulgulandıktan sonra, bu etkinin izleyici etkileşimi özelinde nasıl bir aksiyona dönüştüğü de araştırma sürecinde yanıtlanmaya çalışılmaktadır. Araştırmanın orijinal karma metodolojisine geçmeden önce, ASMR tekniği üzerinde biraz daha derinleşmekte yarar görülmektedir.

\section{ASMR'yi Tanımlamak ve Anlamak}

ASMR tekniği ile üretilen videoların popülerleşmeye başlama süreci, Maria takma isimli bir Youtube kullanıcısının 2009 yılında açtığı ve yatıştırıcı bulduğu ses içeriklerini kayıt altına alarak bir araya toplayıp paylaşıma sunduğu "Gentle Whispering" (Nazik Fisıldama) adlı kanala dayandırılmaktadır (McDonnell, 2019; Miller, 2015). Öyle ki Maria'nın fısıldama videoları 1.6 milyon takipçi rakamına ulaşmış ve takipçi sayısının artmayı sürdürdüğ̈̈ bir popülerlik ivmesi kazanmıştır. 

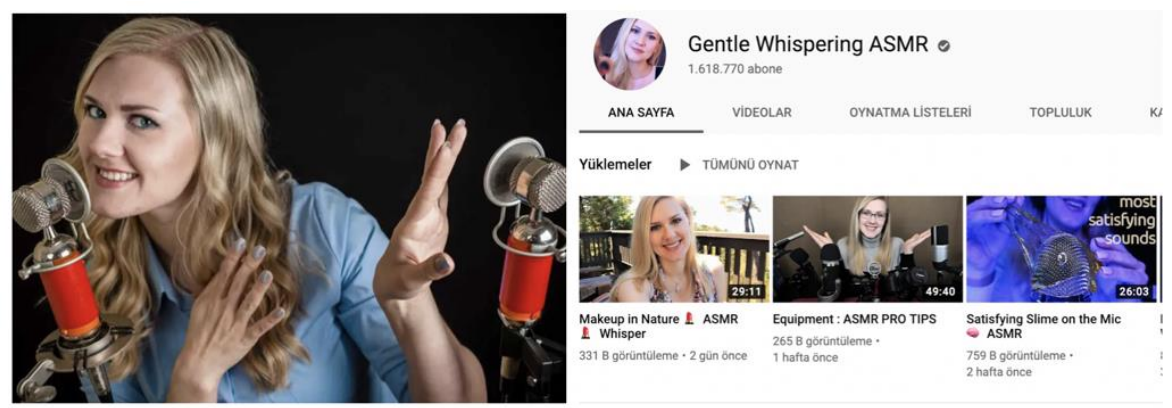

Şekil 3. Gentle Whispering ASMR Youtube Kanalı ve Kanal Sahibi Maria

Kaynaklar: Youtube: (https://www.youtube.com/channel/UC6gLlIAnzg7eJ8VuXDCZ_vg)

Soldaki görsel: (Gibson, 2014)

Erişim tarihi: 14.02 .2019

ASMR videoları genellikle kamera karşısına geçen bir kişinin fısıltıyla ve çok yavaş konuşarak, yavaş el ve vücut hareketleri ile salınarak, kuaför, masör veya sizin için doktor randevunuzu ayarlayan bir asistan gibi profesyonel hizmet veren birini canlandırdığı içeriklerden oluşmaktadır. Bu canlandırmaları yapan içerik sahipleri, ASMR sanatçısı anlamına gelen "ASMRtist" şeklinde bir tabir ile bilinmektedir. ASMR sanatçları mahremiyet ve yakınlık hislerine odaklanan ve bu hisleri yaratmak için çeşitli tekniklerle nesnelerden ses çıkartan ve yavaş el hareketlerini söyledikleri kelimeler ile eşleştiren kişiler olarak da özetlenebilir (Hostler, 2018).

Fısıldama ASMR tekniği dâhilinde kullanılan yöntemler arasında en popüler olanlarından biridir (Barratt ve Davis, 2015). Youtube üzerinde neredeyse her dilde fısıldama temelli ASMR videoları bulmak mümkündür. Fısıldamanın yanı sıra, tırnaklarını nesneler üzerine vurarak ses çıkartma, yumuşak veya sert yüzeylere dokunma, dergi veya kitap sayfalarını çevirme gibi akla gelebilecek türlü nesnenin yüksek kaliteli mikrofonlarla kayıt edilmiş seslerinin yanı sıra dokunsal hislerin de vurgulanmasını sağlayan yine yüksek kaliteli kameralarla kayıt edilmiş yakın plan nesne görsellerinin takip ettiği birçok ASMR video içeriğine rastlanmaktadır. Bu içeriklerin tamamı, kullanıcıların çoğunluğu tarafından benzeri şekillerde reaksiyon almakta ve popüler dolaşımını sürdürmektedir. Bu bağlamda ASMR videolarının seyirlik deneyim dâhilinde, kullanıcılarının zevk ve tatmin dolu duygularını ortaya çıkardığı, hatta kafa derisi ve 
omurgalarında karıncalanma ve ürpertilere neden olan, trans benzeri bir rahatlama hali sunduğu ifade edilmektedir (Copeland, 2017).

Tablo 1. Temel ASMR Uyaranlan (Barratt ve Davis, 2015, s. 6)

\begin{tabular}{|l|l|}
\hline Uyaran Türü & Uyarılan Katılımcıların Yüzdesi \\
\hline Fisıldama & $75 \%$ \\
\hline Kişisel Dikkat & $69 \%$ \\
\hline Gevrek Sesler (aleminyum folyo, tıkırdatılan tırnaklar vb.) & $64 \%$ \\
\hline Yavaş Hareketler & $53 \%$ \\
\hline Tekrar Eden Hareketler & $36 \%$ \\
\hline Gülümseme & $13 \%$ \\
\hline Uçak Sesi & $3 \%$ \\
\hline Elektrik Süpürgesi Sesi & $2 \%$ \\
\hline Kahkaha & $2 \%$ \\
\hline
\end{tabular}

Otonom duyusal meridyen tepki, yani ASMR, bir kavram olarak ilk kez 2010 yılında tanımlanmıştır. Kavramı tanımlayan Jennifer Allen, kendisiyle gerçekleştirilen bir mülakatta sürecin nasıl geliştiğini ifade etmektedir (Richard, 2016): Allen, kendi üzerinde hissettiği ve tanımlayamadığı hisleri ve fiziksel çıktıları adlandırabilmek adına internette araştırmalar yapar ve çeşitli sağlık bloglarında başlıklar açar. Ancak kendisi ile aynı his ve fiziksel çıktıları hisseden insanlar olmasına rağmen, bu ortak çıktıyı bir isimle tanımlayan ve bir çerçeve altında toplayan bir içerik bulamaz. Bu bağlamda ASMR'yi bir tanım olarak ortaya koyar ve bu tanım kullanıcılar tarafından hızla sahiplenilerek ASMR başlığı altında tartışan, içerik üreten ve etkileşime giren kitleleri kendine çekmeye ve böylelikle popülerlik bağlamında kamuoyu gündemini meşgul etmeye başlar. Bu sayede hem psikolojik hem de fiziksel çıktıları olan bir fenomenin adı klinik olmayan bir tabir olarak ortaya konulmuş olur. Kavram bir isimle tanımlandıktan sonra, kavrama dair kullanıcıların popüler ilgisi ve ASMR temelli içerik üretimi artar ve takiben akademik alan da ASMR ile ilgilenir duruma gelir (Copeland, 2017). 
ASMR için "beyin orgazmı" ve "fısıldama pornosu" gibi tabirlerin kullanımına da yaygın olarak rastlanmaktadır (Hostler, 2018). ASMR videolarının mahremiyet ve yakınlık hislerini uyardığ 1 ve "ASMRtist"lerin çoğunluğunun genç ve seksi tavırlar sergileyen kadınlar olduğu gözlemlense de gerçekleştirilen araştırmalar, ASMR'nin izleyicileri üzerinde meditatif bir seviyede rahatlama sağladığı ve seks dürtüsünden uzak bir kaygı giderici, rahatlatıcı olarak çalıştığını bulgulamaktadır (Barratt ve Davis, 2015; Poerio, Blakey, Hostler ve Veltri, 2018). Bu çerçevede çoğu ASMR videosu ortak içerikler bağlamında, rol yapma ve çeşitli meslekleri canlandırma veya kişisel ilgi-deneyim ve özel dikkat videolarından oluşmaktadır. Hatta Hostler (2018) Bob Ross'un 1980 tarihli meşhur televizyon serisi “Resim Sevinci"nin, böyle bir niyetle üretilmemiş olmasına rağmen ASMR içeriklerinin klasikleri arasında yerini aldığı; Bob Ross'u dönemi dâhilinde izleyememiş olan yeni Youtube temelli hedef kitle için böyle yeni bağlam ifade ettiğini söylemektedir.

2015 yılında ASMR kavramına ait ilk akademik çalışma hakemli bir dergide yayınlanarak, kavrama olan akademik ilginin somutlaşması sağlanmıştır (Barratt ve Davis, 2015). Çalışma ASMR etkisinin tarif edilmesine yönelik bir içerik ele almaktadır ve bu bağlamda 475 kullanıcı ile anket ve gözlem gerçekleştirilmiştir. Çalışma kapsamında kullanıcıların "tatlı bir ürperti/çınlama" (the tingles) olarak tarif ettikleri, ASMR videoları ile girilen etkileşimin sonucu olan his tanımlanmakta; ASMR içeriklerinin yarattığ1 uyku hali ve stresle mücadeleye olumlu etkilerinin sonuçlarına yer verilmektedir. Çoğu katılımcı bu tarz içerikler izledikten bir süre sonra kendisini daha iyi hissettiğini ifade etmekte hatta kronik ağr1 çeken bazı katılımcıların, bu ağrılarında ASMR içeriklerinin etkileşimine bağlı azalma olduğu raporlanmaktadır (Barratt ve Davis, 2015, ss. 8-9).

ASMR içerikleri her kullanıcıyı farklı düzeyde etkilemektedir. Kimi kullanıcılar sayfa çevirme sesinden büyük bir tatmin duygusu elde ederken, kimi kullanıcılar bir gülüşte veya tıkırtıda karşılık bulmakta; kimileri ise hiçbir içerik bağlamında ASMR deneyimi yaşamamaktadır (Maxouris, 2019; Richard, 2017). Poerio ve arkadaşları (2018) tarafından gerçekleştirilen, iki ayrı ASMR bağlamını inceleyen çalışma da tüm bu bulguları desteklemektedir. Çalışma dahilinde bir geniş ölçekli çevrimiçi anket ve bir laboratuvar çalışması gerçekleştirilmiştir. Her iki boyutta da ASMR içeriklerinin olumlu etkilerinin ASMR deneyimini yaşayabilen kullanıcılar 
üzerinde belirdiği; ASMR'nin kronik ağrı çekilen durumlarda geçici süreli rahatlamaya neden olduğu, kalp ritmini yavaşlattığı ve endorfin salınımını arttırarak stresle baş edilmesini desteklediği bulgulanmıştır (Poerio vd., 2018).

Barratt ve arkadaşlarının (2015; 2017) ve Poerio ve arkadaşlarının (2018) gerçekleştirdikleri ASMR araştırmaları, ASMR çalışmaları içinde zemin oluşturan ve geniş katılımcı evreni ile gerçekleştirilen çalışmalar olarak ASMR literatürünün merkezini oluşturmaktadır. Bu çalışmaların bulguları ve ilerleyen süreçler için önerileri üzerinden ASMR literatürü şekillenmekte ve bilimsel çalışmalar sürdürülmektedir. Çeşitli bloglar, dergiler ve haber siteleri ise ASMR kavramını popüler bir fenomen olarak ele almakta ve kavramın daha da popülerleşmesine yol açmaktadır. Bu kapsamda, ASMR içeriklerine ilgi duyan ve bu bağlamda psikolojik ortak deneyimler yaşayan kullanıcıların bir araya geldiği, benzer durumlarını tartıştığ 1 ASMR üniversitesi adlı bir web sitesi de bulunmaktadır. Siteyi kurgulayan ve içeriğini yürüten Craig Richard, site üzerinden etkileşime geçtiği kullanıcılarla görüşmeler yaparak, ASMR fenomeni ile ilgili topladığı veri setini genişletmektedir. Bu çerçeve dâhilinde gerçekleştirilen araştırmada şimdiden 100 farklı ülkeden, 20 bini aşkın kullanıcıdan sahip oldukları ortak tatlı ürperti ve çınlamalara dair veri elde edilmiştir (Richard, 2016). Bu web sitesi üzerinden sürdürülen çalışma, akademik araştırmaların yanı sıra ASMR'ye dair sosyal platformda da yürütülen en kapsamlı çalışma olarak devam etmekte; ASMR'ye dair akademik ve topluluk taraflarını birbirine bağlamaktadır.

\section{Yöntem}

ASMR videolarının genel rahatlama hali, kaygı düşürücü etkisi ve diğer pozitif çıktıları, çeşitli anket, gözlem ve kullanıcı yorumları teknikleri ile geniş katılımcı evrenleri düzeyinde araştırılmıştır (Barratt ve Davis, 2015; Barratt vd., 2017; Poerio vd., 2018). ASMR' in beyin ve otonom sinir sistemi üzerindeki etkisine yönelik çalışmalar ise ilk kez Smith ve arkadaşları (2017) tarafından gerçekleştirilmiş; ancak otonom sinir sistemi üzerindeki etkileri bulgulamaya çalışan bu tarz araştırmalar, daha dar bir kapsamda kalmıştır. 
Smith ve arkadaşlarının (2017) çalışmasında ASMR videolarının etki ettiği alanları gözlemlemek için biyometrik veri toplama tekniklerinden fMRI yöntemi kullanılmış ve içeriklerin beynin varsayılan ağ durumu (DMN) üzerindeki etkisi 22 kullanıcı üzerinde incelenmiştir. Çalışmadan elde edilen bulgular ile ASMR videolarının beynin kendisini dinlenmeye aldığ1 ve sakinleştirdiği çoklu durum ve diğer bölgelerle olan ilişkisi saptanmıştır. Ancak Copeland (2017) Smith ve arkadaşları ile gerçekleştirdiği mülakatta, fMRI makinelerinin çok gürültülü çalıştı̆̆ı, EEG gibi beyin dalgalarını ölçen tekniklerin ise birçok kablo ve sensör barındırdığı için bu tarz yöntemlerin aynı zamanda dikkat dağıtıcı olduğunu ve rahatlama etkisine engel olabilecek durumlar yarattığını da aktarmaktadır. Bu nedenle araştırma dahilinde, Smith ve arkadaşlarının (2017) yaklaşımına benzer bir biyometrik veri toplama sürecine girilmesine rağmen, katılımcıları prosedür esnasında daha az rahatsız edici bir teknik olan deri iletkenliği ölçümüne (GSR) başvurulmaktadır.

Sempatik otonom sinir sistemi elektrodermal etki düzeyinde deri iletkenliği ölçümü (GSR) tekniği ile gözlemlenmekte ve ilgili biyometrik veri, kalp hacim durumu (PPG) üzerinden dönüştürülen elektrokardiyografi (EKG) verisi ile nabız değişkeni çıktısı olarak ele alınmaktadır (Boucsein, 2012). Elektrodermal etkinin ölçümlendiği GSR tekniği, kullanıcılara minimum düzeyde rahatsızlık verecek şekilde tasarlanmış; az sayıda bağlantı noktası bulunan, kolay kurulum ve kullanım özelliği olan bir biyometrik veri toplama cihazından veri alınması prensibine dayanmaktadır. Böylelikle Smith ve arkadaşlarının Copeland'a (2017) aktardıkları boyutlarda teknik sorunlarla karşılaşılmasına engel olmak amaçlanmıştır. Elde edilen bu nicel veri seti, gözlem, kullanıcı testi ve derinlemesine görüşme yöntemleri ile nitel olarak da desteklenmektedir.

\section{Katılımcılar}

Çalışma 5 kadın ve 5 erkek katılımcıdan oluşan, 20-40 yaş arası toplam 10 kullanıcı-izleyici ile gerçekleştirilmiştir. Bu noktada katılımcı grubunun hedef kitle olarak özellikle $Y$ kuşağına denk gelecek şekilde bir yaş aralığına ait olması düşünülmüştür. İcil Tuncer ve Tuncer'e göre (2016, s. 214) toplulukta varlık gösteren çeşitli jenerasyonların, hayat tarzlarını etkile- 
yen teknolojik yeniliklerle etkileşimlerine göre farklı yaşam biçimleri sürdürmeleri söz konusudur. Bu bağlamda Y kuşağı, 2000'li yıllardan sonra teknolojinin içine doğan ve sosyalleşme aracı olarak sosyal medyayı kullanan Z kuşağından farklıdır (Hammill, 2005). 1960 ve 70'li yıllarda doğan, internet ve sosyal medya gibi teknolojiler ile 40 'lı yaşlarına yakın tanışan $X$ kuşağına göre ise teknoloji bağlamında çok daha etkilidir (Howe ve Strauss, 1992). Bu çerçevede, 1980'lerden sonra doğan, yeni teknolojilere büyürken tanık olan, kendini ifade etmeyi önemseyen ve karar alımında aktif olmayı seven Y kuşağı (Howe ve Strauss, 1992; İcil Tuncer ve Tuncer, 2016), ASMR içeriklerinin seyirci deneyimi üzerindeki etkisini gözlemlemek için en uygun yaş grubu olarak benimsenmiştir.

Bu yaş aralığı aynı zamanda Türkiye'de interneti en aktif kullanan ve sosyal medya içerikleri ile en çok etkileşime giren kullanıcı grubuna da dâhildir (Social, 2018). Hootsuite ve We Are Social'ın 2018 yılı raporuna göre, Türkiye'de 51 milyon aktif sosyal medya kullanıcısı bulunmaktadır ve bu kullanıcıların yüzde 55'i gibi çok yüksek bir ortalama ile Youtube en yoğun kullanılan sosyal medya platformudur. Bu kullanıcıların yüzde 64 'ü ise Youtube videolarını günlük olarak izlediklerini ifade etmektedir. $\mathrm{Bu}$ kullanıcıların ortalama yaşı ise 31.4 olarak saptanmış ve kullanıcıların yüzde 70'i internetin risk yaratmaktan öte firsatlar sunan bir yapıda olduğu görüşünde fikir beyan etmiştir. Beyan edilen bu ağırlıklı görüş, $Y$ kuşağının Howe ve Strauss'un (1992) tanımladıkları yapısal özellikleri ile de örtüşmektedir. Bu bağlamda hem yaş aralığı ile temsil ettikleri kuşağın bir özelliği olarak hem de internet ve sosyal medya kullanım alışkanlıkları özelinde, ASMR içeriği ile sıklıkla karşılaşan ve bu karşılaşma esnasında sorunsuz bir seyirlik etkileşim yaşama potansiyeli yüksek olan bir örneklem grubundan bahsedilmektedir.
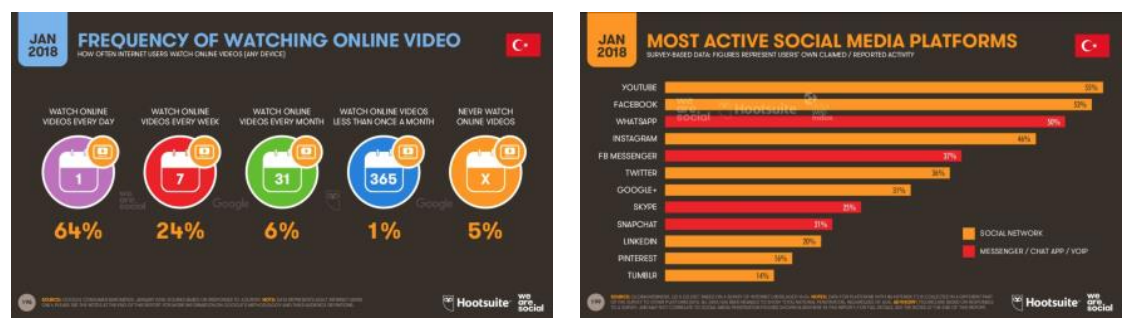

Şekil 4. Hootsuite ve We Are Social 2018 Raporundan Örnek Veriler (Social, 2018) Erişim tarihi: 16.02.2019 
Aynı rapor dâhilinde, Türkiye'deki aktif internet kullanıcılarının reklamlara yönelik ilk farkındalık mecrası ise yüzde 35 gibi bir oranla çevrimiçi kanallar olarak bildirilmektedir. Veriler doğrultusunda, seçilen örneklem grubunun ASMR içeriklerine yönelik araştırılan yapı dâhilinde, sonuçları temsil etme gücü en yüksek grup olduğunu ifade etmek mümkündür.

\section{ASMR İçeriklerinin Seçimi}

Barratt ve arkadaşlarının (2017) gerçekleştirdiği daha yeni bir çalışmada bu kez ASMR videolarının, izleyicilerinin uyarılmasını sağlayan şartları ve bu şartlara bağlı tetikleyici durum değişkenleri incelenmiştir. Çalışmaya katılan 130 izleyicinin yüzde 38'i, 1-5 dakika arasındaki seyir deneyimleri esnasında ASMR uyarımı yaşamıştır. Bu oran, ASMR etkisinin en sık görüldügü zaman aralığı olarak bulgulanmıştır. Bu bulgular üzerinden çalışmada da gösterim için seçilen videolarda 1-5 dakika arası zaman aralığı gözetilmiştir.

Tablo 2. Popüler ASMR İçeriklerinin Tetikleme Süreleri (Barratt vd., 2017, s. 5)

\begin{tabular}{|l|l|}
\hline $1-5$ dakika & $38 \%$ \\
\hline $6-10$ dakika & $30 \%$ \\
\hline $11-20$ dakika & $\sim 15 \%$ \\
\hline 21 dakika veya daha fazla & $15 \%$ \\
\hline
\end{tabular}

Videolar için zaman aralığı belirlendikten sonra, Barratt ve Davis'in (2015) ilk çalışmasında belirlenen temel ASMR uyaranları tablosuna (bkz. sayfa 7) dikkat edilerek, popüler ASMR videoları ve reklam filmleri arasından, 3 reklam filmi ve 2 Youtube için hazırlanmış içerik olmak üzere 5 videoluk bir seçki oluşturulmuştur. 
Tablo 3. Gösterim için Seçilen ASMR İçerikleri

\begin{tabular}{|c|c|}
\hline $\begin{array}{l}\text { Michelob ULTRA "Saf Deneyim", } \\
\text { Super Bowl } 2019 \text { Reklam Filmi } \\
\text { https://youtu.be/LXmlN9BAddg } \\
\mathbf{1 4} \text { milyon izlenme }\end{array}$ & $\begin{array}{l}\text { Fısıldama, Kişisel Dikkat, Gevrek Sesler } \\
\text { (tıkırdama), Yavaş Hareketler ve } \\
\text { Gülümseme }\end{array}$ \\
\hline $\begin{array}{l}\text { Safeguard Sunar "The Wash" } \\
\text { ASMR Reklam Filmi } \\
\text { https://youtu.be/RbGCKGuJD10 } \\
\mathbf{1 . 8} \text { milyon izlenme }\end{array}$ & $\begin{array}{l}\text { Fısıldama, Gevrek Sesler (tıkırdama, hışırtı, } \\
\text { şarıltı, patırtı vb.), Yavaş Hareketler ve } \\
\text { Tekrar Eden Hareketler }\end{array}$ \\
\hline $\begin{array}{l}\text { Sihua Dove "Angelbaby" } \\
\text { ASMR Reklam Filmi } \\
\text { https://youtu.be/EhwYbH5n15c } \\
\mathbf{6 1} \text { bin izlenme }\end{array}$ & $\begin{array}{l}\text { Fısıldama, Gevrek Sesler (hışırtı, şapırtı), } \\
\text { Yavaş Hareketler, Tekrar Eden Hareketler } \\
\text { ve Gülümseme }\end{array}$ \\
\hline $\begin{array}{l}\text { Gentle Whispering ASMR Youtube Kanalı } \\
\text { Basit Zevkler, Yumuşak Konuşma ve } \\
\text { Kişisel Dikkat Videosu } \\
\text { https://youtu.be/B8jUVci17vE } \\
\mathbf{1 7} \text { milyon izlenme }\end{array}$ & $\begin{array}{l}\text { Fisıldama, Yavaş Hareketler, Tekrar Eden } \\
\text { Hareketler, Gülümseme ve Kişisel Dikkat }\end{array}$ \\
\hline $\begin{array}{l}\text { 10-Minutes Amazing Life Youtube Kanalı } \\
\text { ASMR Uyku için Sabun Kazıma } \\
\text { Rahatlatıc1 Sesler Videosu } \\
\text { https://youtu.be/bjd4ykxd7VU } \\
\mathbf{8 . 7} \text { milyon izlenme }\end{array}$ & $\begin{array}{l}\text { Yavaş Hareketler, Tekrar Eden Hareketler } \\
\text { ve Gevrek Sesler (tıkırdama, kıtırdama, } \\
\text { takırdama, vb.) }\end{array}$ \\
\hline
\end{tabular}

Kaynak: İlenme oranları ve kaynak videolar Youtube üzerinden alınmıştır.

Erişim tarihi: 18.02.2019

\section{Prosedür}

Araştırmanın karma yöntem yaklaşımı dâhilinde, katılımcılardan nicel ve nitel veriler, belirli bir uygulama prosedürüne sadık kalınacak şekilde bir arada alınmıştır. Bu bağlamda nitel verileri toplamak için gözlem ve derinlemesine görüşme teknikleri kullanılmıştır. Gözlem, katılımcılar ile gerçekleştirilen geleneksel saha çalışmalarının temel kurgusunu oluşturmanın yanı sıra, teknoloji bağlamında hareket edilen kullanıcı araştırmalarının da ana unsurlarından biridir. Derinlemesine görüşme ise gözlem yapan araştırmacının, süreci samimi bir sohbet ortamında yönlendirdiği ve önceden belirlenmiş soru başlıklarının gündemi ile hareket ederek, katılımcıların tutum, görüş, duygu ve inançlarına ilişkin kesintisiz ve derinlikli bilgi edinebildiği, karşılıklı sözlü iletişime dayalı bir süreci temsil etmektedir (Briggs, 1986). 
Araştırmanın nicel tarafında ise elektrodermal aktivite GSR cihazı ile kayıt altına alınmış ve aynı cihaz ile nabız verisinin de ölçümü gerçekleştirilmiştir (Boucsein, 2012; iMotions, 2017). Böylelikle katılımcların motivasyonel durum değişiklikleri nicel olarak saptanmış ve nitel olarak kullanılan tekniklerin yardımı ile duygu durumlarına dair veriler bulgulanmıştır. Bu karma yöntem yaklaşımı ile ASMR içeriklerinin neden olduğu ifade edilen stres seviyesindeki azalma, ürperti, tetiklenme, uyarım, rahatsızlık, gerilim ve benzeri duygu durumlarının yakalanıp, yorumlanabilmesi mümkün olmuştur. Bu karma yöntem dahilinde katılımcılar seçili ASMR içeriklerini tek başlarına ve rahatsız edilmeden deneyimleyebilecekleri bir ortama davet edilmiştir. Katılımcıların seyirlik deneyimleri esnasında mekanda sadece gözlem yapan araştırmacı yer almıştır. Katılımcılara, GSR cihazı bağlandıktan sonra, aşağıdaki prosedür her bir katılımcıda aynı trafikte devam edecek şekilde, toplamda 20-25 dakikalık bir süreç olarak uygulanmıştır:

- Katılımonin demografik verileri ve ASMR içerikleri hakkında bilgi sahibi olup olmadığına dair ön bilgi alınmıştır. Prosedürde yer alan aşamalar ve hangi içeriklerin gösterileceğine ve GSR cihazının nasıl çalıştığına dair ön bilgi verilmiştir. Bu esnada katılımcının elektrodermal verilerinin doğru alınabilmesi için gerekli olan alışma süresi de tamamlanmıştır.

- Seçilen içerikler katılımcılara sunulmuştur. Her bir içeriğin gösteriminin ardından, katılımcının hissettiği duyguyu ve fiziksel tepkiyi (uyarım/tetikleme) dile getirmesi istenmiş ve gözlenen durum not edilmiştir.

- Seyir deneyimi esnasında yapılan gözleme dayanarak, oluşması muhtemel ASMR etkisini tarif etmeleri, fiziksel olarak yerini ve şiddetini tanımlamaları istenmiştir. Yaşanan etkinin psikolojik olarak da detaylı tarifi katılımcılardan talep edilmiş ve veriler not edilmiştir. Prosedürün bu aşaması Poerio ve arkadaşlarının (Poerio vd., 2018, ss. 5-10) kullandığ1 "etki" ve "tetikleme frekansı" çalışma başlıklarından referans alınarak kurgulanmıştır.

- Özel olarak reklam filmi içerikleri üzerinden ürün ve marka hakkında ne düşündükleri ve ASMR içeriğinin bu düşüncelerini nasıl etkilediği sorulmuştur. 
- Videolar sonrası genel akışa dair gözlemlenen ve kayıt altına alınan motivasyonel durumları katılımcılara gösterilerek, derinlemesine görüssme ile ASMR hakkında oluşan yeni düşünceleri, his farklılıkları, hangi içerikten hoşlandıkları, hangisini rahatsız edici buldukları; ASMR içeriklerinin ürün veya hizmet alımına yönelik katılımcılar üzerindeki istek, arzu, güven ve marka itibarı etkisi gibi durumlar anlaşılmaya çalışılmıştır.

\section{GSR Cihazının Parametreleri ve Kullanım Metodu}

Elektrodermal ve nabız verileri Shimmer GSR+ cihazı ile kayıt altına alınmış ve eş zamanlı olarak ConsensysPRO 1.5.0 yazılımı ile analiz edilmiştir (Shimmer, 2019). Shimmer GSR+ donanımı eş zamanlı geri bildirim yapan 3 kanala sahiptir. Bu kanallardan 2 tanesi elektrodermal veriyi işaret ve orta parmaklara bağlanan el sensörleri ile kayıt altına alırken, diğeri ise kalp hacim verisini (PPG) sol kulağa takılan kızılötesi sensörden toplayarak, yazılımın algoritması aracılığı ile elektrokardiyografik (EKG) kalp nabız verisine dönüştürmektedir. Ekipman kalp ritmini ve deri iletkenlik seviyesini hem katılımclar seyir deneyimine başlamadan önce hem de videoları izlerken kayıt etmiştir. Reklam videoları için sürenin sonuna kadar, Youtube içerikleri için ise maksimum 5 dakika olacak şekilde kayıt alınmış ve bu veri izlenen videonun özelinde analiz edilmiştir.

GSR tekniği ile bilinçli olarak kontrol edemeyeceğimiz, bilinçdışı davranışlar ölçüm altına alınmaktadır. Vücudumuzun en büyük organlarından biri olan deri; idrak halimiz ve duygu durumumuzdaki bilinçdışı uyarılmaların tamamına tepki göstermektedir. Bu tepki, otonom sempatik sinir sistemi tarafından idare edilen bilinçdışı bir sisteme bağlıdır ve deri iletkenliği seviyesindeki değişiklikler ile gözlemlemek mümkündür. Bu bilinç düzeyi ile kontrol altına alınamayan durum, GSR ölçüm tekniğini, duygu durumu ve motivasyonel değişimi ölçümlemek adına ideal bir biyometrik veri toplama aracı haline getirmektedir (iMotions, 2017, s. 5). 


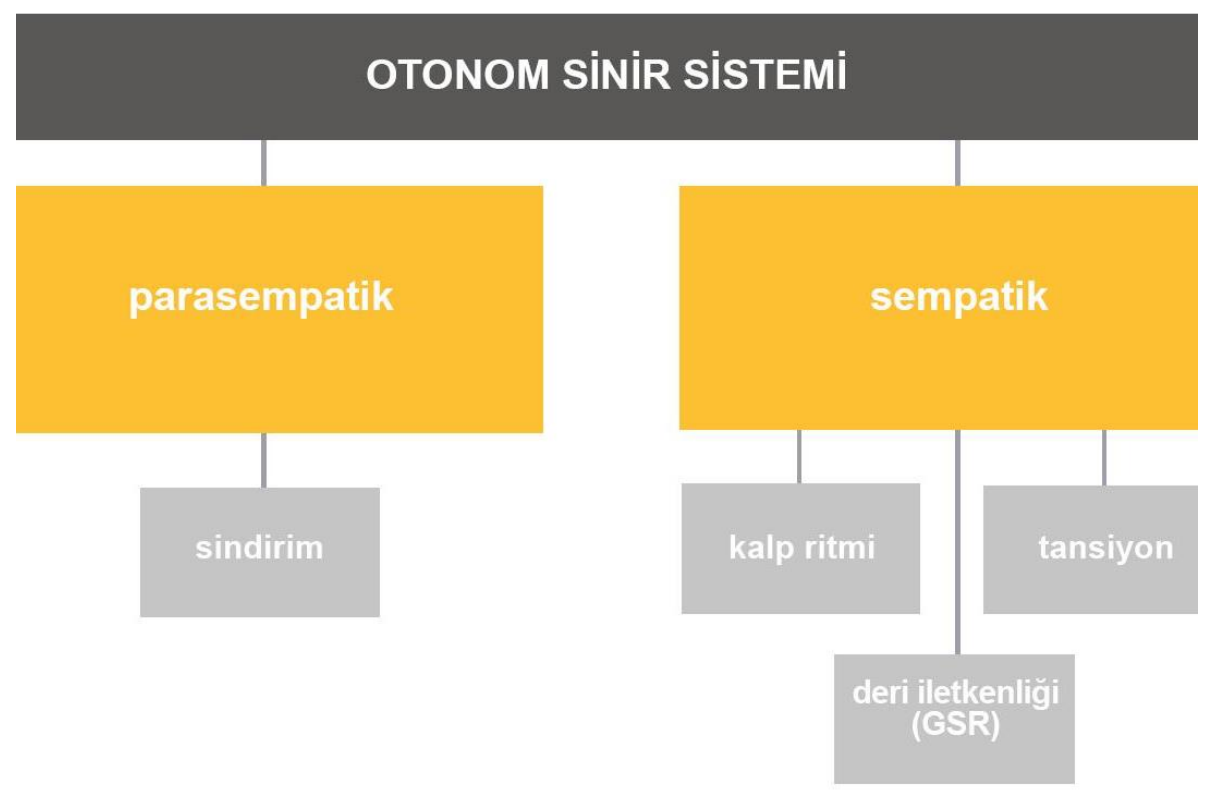

Şekil 5. Otonom Sinir Sistemi (iMotions, 2017, s. 7)

Diğer otonom süreçlerde olduğu gibi (ateş, kalp ritmi, tansiyon vb.) terleme hali de bilinçli olarak kontrol altına alınamaz. Deri iletkenliği de bu otomatik terleme halinden etkilenmekte, bu durum ise GSR ile takip edilmektedir. Bu bağlamda durum değişkenine göre, kaç veya savaş tepkisi üreten otonom sempatik sinir sistemi, otomatik bir uyarı mekanizması gibi çalışmakta ve bilinçaltı düzeyde yönettiği merkezler ile duruma göre tepki vermektedir. 1972 yılından bu yana otonom sinir sisteminin sempatik tepkilerine odaklanan ve GSR tekniği ile ölçüm altına alınan 1500' ̈u aşkın makale yayınlanmıştır ve teknik bilimsel anlamda en güvenilir ölçümlerden biri olarak literatürdeki yerini almıştır (Boucsein, 2012).

Araştırma esnasında GSR cihazına bağlanan katılımcılardan 2 farklı veri alınması tasarlanmıştır. Bu bağlamda birinci veri deri iletkenlik seviyesi (SCL) değeridir. Bu veri katılımcının içinde bulunduğu motivasyonel durum esnasındaki uyarılma hali seviyesini vermektedir. Toplanacak olan diğer veri ise nabız verisi (bpm) olacaktır. Nabız verisi diğer veri ile 
birlikte okunarak, katılımcının ASMR içeriklerine dair otomatik motivasyonel tepkilerinin anlaşılmasında biyometrik rehberlerden biri olarak işlev görmektedir.

\section{Bulgular ve Tartışma}

Araştırmanın temel sorusu üzerinden çalışma dahilinde iki ana yönelim ile hareket edilmiştir. Bu noktada ASMR tekniği ile üretilen içeriğin bahsedilen psikolojik ve fiziksel rahatlama ve sunulan seyirlik odağa dikkati toplama etkilerinin, profesyonel medya ve iletişim içeriği üretimi bağlamında ne kadar kullanışlı olduğu konusu tartışmaya açılmaktadır. ASMR'nin yarattığı etki biyometrik veri olarak kayıt altına alındıktan sonra, elde edilen bulguların izleyici etkileşimi özelinde nasıl bir aksiyona dönüştügü de süreç dahilinde incelenmektedir. Gerçekleştirilen saha çalışması neticesinde 5 ASMR video içeriği gösterilen 10 katılımcıdan kalp ritmi ve deri iletkenlik seviyesi (SCL) bilgileri toplanmıştır. Kalp ritmi ve SCL verileri her bir videonun başlangıç (N-1 ve SCL-1) ve bitiş zamanlarına (N-2 ve SCL-2) denk gelecek şekilde kayıt altına alınmıştır.

Tablo 4. Katılımcıların ASMR İçerikleri ile Otonom Sempatik Sinir Sistemi Etkileşimleri

\begin{tabular}{|c|c|c|c|c|c|c|c|c|c|c|c|c|c|c|c|c|c|c|c|c|}
\hline & \multicolumn{4}{|c|}{ Michelob Ultra R.F. } & \multicolumn{4}{|c|}{ Safeguard R.F. } & \multicolumn{4}{|c|}{ Sihua Dove R.F. } & \multicolumn{4}{|c|}{ Gentle Whispering YT. } & \multicolumn{4}{|c|}{ Soap Carving YT. } \\
\hline & $\mathrm{N}-1$ & $\mathrm{~N}-2$ & SCL-1 & SCL-2 & $\mathrm{N}-1$ & $\mathrm{~N}-2$ & SCL-1 & SCL-2 & $\mathrm{N}-1$ & $\mathrm{~N}-2$ & SCL-1 & SCL-2 & $\mathrm{N}-1$ & $\mathrm{~N}-2$ & SCL-1 & SCL-2 & $\mathrm{N}-1$ & $\mathrm{~N}-2$ & SCL-1 & SCL-2 \\
\hline Katılımcı 1 & 72 & 60 & 6,3 & 6,1 & 63 & 60 & 5,8 & 5,1 & 65 & 60 & 5,7 & 5,3 & 65 & 58 & 5,3 & 4,7 & 67 & 58 & 5,8 & 4,8 \\
\hline Katılımcı 2 & 80 & 75 & 2 & 2 & 85 & 70 & 2,5 & 1,7 & 80 & 65 & 3 & 2,6 & 70 & 63 & 4,2 & 3,9 & 70 & 70 & 4,7 & 3,7 \\
\hline Katılımcı 3 & 83 & 75 & 1,8 & 2,5 & 95 & 80 & 3 & 3,5 & 90 & 83 & 3,9 & 5 & 94 & 84 & 5,6 & 5,6 & 90 & 75 & 5,7 & 5,5 \\
\hline Katılımcı 4 & 80 & 75 & 2 & 2,2 & 72 & 70 & 2,3 & 1,6 & 80 & 75 & 1,6 & 1,6 & 75 & 70 & 2,8 & 2,7 & 74 & 72 & 2,8 & 2,5 \\
\hline Katılımcı 5 & 78 & 78 & 1,5 & 1,3 & 78 & 74 & 1,5 & 1,2 & 78 & 78 & 1,7 & 1,5 & 78 & 75 & 2 & 1,8 & 76 & 72 & 2 & 1,8 \\
\hline Katılımcı 6 & 70 & 65 & 0,4 & 0,4 & 68 & 60 & 0,4 & 0,4 & 70 & 60 & 0,4 & 0,5 & 65 & 58 & 0,5 & 0,5 & 73 & 66 & 0,8 & 0,7 \\
\hline Katılımcı 7 & 80 & 71 & 1,4 & 1,4 & 75 & 63 & 1,9 & 1,3 & 72 & 67 & 2,5 & 2,4 & 83 & 72 & 3,6 & 2,6 & 74 & 70 & 4,2 & 3,2 \\
\hline Katılımcı 8 & 100 & 83 & 0,9 & 0,9 & 94 & 89 & 1,4 & 1 & 90 & 83 & 1,4 & 1,1 & 85 & 85 & 1,5 & 1,4 & 78 & 83 & 1,8 & 1,5 \\
\hline Katılımcı 9 & 83 & 77 & 1,7 & 1,1 & 70 & 72 & 2,8 & 1,2 & 77 & 63 & 2,1 & 1,4 & 77 & 55 & 1,3 & 0,9 & 75 & 74 & 3,2 & 2 \\
\hline \multirow[t]{3}{*}{ Katilımcı 10} & 60 & 60 & 0,9 & 0,9 & 62 & 60 & 1,2 & 1 & 58 & 62 & 1,2 & 1,4 & 60 & 57 & 1,4 & 0,8 & 56 & 52 & 1,2 & 1,2 \\
\hline & R.F. & \multicolumn{3}{|c|}{ Reklam Filmi } & & & $\mathrm{N}-1$ & \multicolumn{5}{|c|}{ Nabız Video Başlangı̨̧ Değeri } & & & \multicolumn{6}{|c|}{ SCL-1 SCL Video Başlangıç Değeri } \\
\hline & YT. & \multicolumn{3}{|c|}{ Youtube lçeriği } & & & $\mathrm{N}-2$ & \multicolumn{5}{|c|}{ Nabız Video Bitiş Değeri } & & & SCL-2 & SCL Vic & ideo $B$ & itiş De & eğeri & \\
\hline
\end{tabular}

Elde edilen biyometrik veriler üzerinden varılan genel sonuç, katılımcıların Barratt ve Davis (2015) ve Poerio ve arkadaşlarının (2018) iddia ettiği gibi, duyusal anlamda ASMR içeriklerine olumlu tepki verdikleri yö- 
nündedir. Yahoo Lifestyle'dan Haglage’ye (2018) konuşan Poerio; “İnsanların bize sözlü olarak kendilerini çok daha rahat hissettiklerini aktarmalarının yanı sıra aynı zamanda psikolojileri de bize aynı şeyi söylemektedir" ifadesine vurgu yapmaktadır. Araştırma dâhilinde Poerio'nun (2018) bu ifadesinin aksine, bilinç düzeyinde içeriklerden rahatsız olan ve bunu dile getiren kullanıcılar da bulunmaktadır. Ancak, otonom sempatik sinir sisteminden bulgulanan veriler, bazı içeriklerin seyir deneyimi esnasında rahatsızlıklarını dile getiren kullanıcılar da bile daha önceki araştırmaların sonuçlarını destekler nitelikte duyusal bir rahatlama durumunu vurgulamaktadır. ASMR içeriklerini deneyimleyen katılımcıların başlangıç (N-1) ve bitiş (N-2) nabızları ile SCL değerleri (SCL-1 ve SCL-2) arasında belirgin bir düşüş bulgulanmıştır. Bu bağlamda katılımcıların nabız ve deri iletkenlik düzeylerindeki gerilimin azalması, bilinçaltı düzeyde stres seviyelerinin azaldığını, rahatladıklarını göstermektedir.

Bu noktada katılımcılardan elde edilen diğer bulguları da toparlayacak şekilde ele almak ve ardından gösterilen her bir ASMR video içeriği özelinde tartışmayı derinleştirmek yerinde görülmektedir:

- ASMR tekniklerinden etkilenip içerikle etkileşime geçen kullanıcllar kadar bu tekniklerden rahatsız olan, görüntü ve sesleri tiksindirici ve uzaklaştırıcı bulan kullanıcılar da olmuştur. Bu bağlamda, seslerin kullanımından rahatsız olan kullanıcıların "misofonya etkisi" olarak adlandırılan psikolojik tanıma yakın bir çıktı sağladıkları gözlemlenmiştir

- Kimi içerikler ile izleyicilerin etkileşimi düzeyinde ise çoklu duyusal uyarım, yani "sinestezi etkisi" bulgulanmıştır.

- ASMR içeriklerinin görsel ve işitsel teknik ile birlikte medya ürünü olarak görsel estetik kalitesi, hem ASMR etkisinin oluşması hem de seyirlik deneyim adına önemli bir belirleyici olmuştur.

- Youtube içeriklerinin reklamlardan seyirlik etkileşim düzeyinde daha fazla rahatlatıcı ASMR etkisi yarattığı; reklam filmlerinde ASMR tekniğinin kullanımının ise hedef kitleye göre özel koşullar ve anlatı yapısı gerektirdiği koşulu bulgulanmıştır.

- Belirli içeriklerde cinsel uyarımın varlığı belirgin bir şekilde vurgulanmış ve bu durumun çoğu zaman sunulan ürün veya hizmetin önüne geçtiği görülmüştür. Katılımcıların belirli durumlarda 
arketip tanımları üzerinden hareket edip, içeriklere dair yorumlarını bu düzlemde yaptıkları; cinsel uyarım etkileşimi sağlayan içeriklerin de bu bağlamda arketip özellikler üzerinden okunabileceği gözlemlenmiştir.

ASMR içerikleri tarafından belirli bir tetiklenme ve uyarım durumu yaşadığını ifade eden katılımcılar bu etkiyi genellikle omurgalarının üst kısminda ve boyunlarının arkasında bir ürperti ve karıncalanma olarak hissettiklerini söylemektedir. Bu durum Barratt ve Davis'in (2015, s. 8) "ASMR haritası" adı altında belgeledikleri; ASMR'nin vücutta tetiklendiği alanları aktardıkları bulgu ile benzer bir şekilde çalışmaktadır. Katılımclardan biri, Gentle Whispering Youtube videosunu izlerken içinde bulunduğu deneyim halini "çok rahatladım, başımın arkasında bir salınma ve ürperti yaşadım. Bilgisayar üzerinden Maria'ya sarılma hissi geldi" (Katılımc1 7, kadın, 36 yaş) ifadesi ile vurgulamıştır. Bir diğeri ise "ekrandan geri çekilme ve kapatma hissi geldi, taciz ediliyorum zannettim ve seslerden de çok rahatsız oldum..." (Katılımcı 3, erkek, 29 yaş) açıklaması ile yaşadığı ASMR etkisini tarif etmeye çalışmıştır. Katılımcı 3'ün ifade etmeye çalıştığı bu olumsuz durum, hem Maxouris (2019) hem de Richard'ın (2017) belirttiği; ASMR tekniği ile düzenlenmiş içeriklerin her kullanıcı için uygun olmadığı ve kimi izleyiciyi için rahatsızlık veren bir deneyim yaşatabildiği ve hatta izleyiciyi ürküttüğü noktalarını da hatırlatmaktadır. Bu bağlam, misofonya olarak adlandırılan ve ASMR'nin tam tersi bir etkinin tetiklenmesine neden olan, belirli seslerden aşırı derecede rahatsız olma ve olumsuz duygusal tepki verme süreci olarak tanımlanmaktadır (Barratt ve Davis, 2015, s. 12). Misofonya'yı ayırt etmek adına tanımlamak gerekirse; seçili seslere karşı duyulan kin (Young \& Blansert, 2015) veya yüksek sesle nefes alıp verme, burundan çıkan sesler, kara tahtaya veya duvara tırnak sürtünmesi, metalin tabakta çıkardığı etki gibi; kişilerde iğrenme, öfke ve rahatsızlık tepkisine neden olabilen sesler, durumu en iyi şekilde örnekleyecektir (Schröder, Vulink ve Denys, 2013).

Bulgular, katılımcıların bazı durumlarda da çoklu duyusal uyarım olarak adlandırılan sinestezi etkisi yaşadıklarını göstermektedir. Bu durum dışsal uyaranların etkileşim kurduğu birincil duyunun yanı sıra ikincil bir duyunun da içsel olarak harekete geçmesi olarak tarif edilmektedir (Banissy, Jonas ve Cohen Kadosh, 2014). Bir başka deyiş ile sinestezi etkisini; 
müzik notalarının her birinin bir renk olarak görülmesi, görüntüde yer alan yiyecek veya içeceğin tadının da hissedilmesi veya yine gösterilen bir nesnenin dokusunun sert mi yoksa yumuşak mı olduğunun anlaşılması olarak da tanımlamak mümkündür. Bu çerçevede katılımcılardan biri Safeguard sabun reklamını izledikten sonra; "havlunun yumuşaklı̆̆l hissettim ve sabunun kokusu burnuma geldi, üstelik sabunun ne kadar kaygan olduğunu da algıladım, bir bakıma birçok duyuyu aynı anda hissettim" şeklinde seyirlik deneyimini ifade etmiştir (Katılımcı 8, kadın, 40 yaş). Bir başka katılımcı ise Sihua Dove çikolata reklamını seyrederken "yedim ben bunu, tadı geldi ağzıma... önüme 3-4 farklı çikolata koysanız, onların içinde hemen tadını ayırabilirim" şeklinde ASMR tekniği ile kurgulanan anlatının neden olduğu seyirlik deneyimini belirtmiştir (Katılımcı 7, kadın, 36 yaş). Gentle Whispering Youtube videosunda baskın olarak yer alan kişisel odak ve dokunma ASMR tetikleyicileri ise çoğu katılımcının üzerinde dokunma hissini keskin bir şekilde yaratmıştır. Kimi kullanıcı bu duruma olumlu bir etki ile yanit verirken, dokunulma hissinden rahatsiz olanlar ise durumu "özel ve mahrem alanın ihlali ve bu alana müdahil olunması" şeklinde yorumlamıştır (Katılımc1 2, 3, 6 ve 8).

Duyuların birlikteliği ile tetiklenen süreç, ASMR'nin bir başka özelliği olan dikkat, odaklanma ve farkındalık noktasındaki olumlu etkisini de marka iletişim süreçleri bağlamında gündeme getirmektedir. Fredborg ve arkadaşlarının (2018) 284 katılımcı ile gerçekleştirdikleri araştırmanın sonuçlarına göre; ASMR etkisi, dikkat, merak, farkındalık ve odaklanma başlıklarında deney grubunda yer alan katılımcıların, kontrol grubunda yer alan katılımcılara göre çok daha yüksek performans sergiledikleri sonucunu ortaya koymaktadır. Elde edilen bu bulgular, ASMR'nin farkındalık ile yüksek ilginliğini ifade etmektedir. Bu ilişki dâhilinde, ASMR tekniğinin profesyonel reklam endüstrisinde varlık göstermesinin nedeni ve tekniğin marka iletişimi bağlamında doğru kullanımının önemi de vurgulanmaktadır. Katılımcılardan elde edilen bulgular, ASMR içeriklerinin yoğun bir duyusal deneyim yaşattığını, ancak bu duyusal deneyimin her zaman olumlu bir şekilde sonuçlanmadığını da göstermektedir. Katılımcılar özellikle Safeguard sabun reklamına yüksek oranda olumsuz tepki vermiş̧ir. Bir katılımcı rahatsız olduğu sesler nedeniyle sabunun el y1kama esnasında kendisine zarar verebileceğini düşünmüşs (Katılımc1 5, erkek, 40 yaş); bir başka katılımcı ise reklamda yer alan tüm seslerin çok 
tiksindirici ve rahatsız edici olduğunu ve ürünü kesinlikle almayacağını ifade etmiştir (Katılımc1 9, kadın, 37 yaş). Ürün ile ASMR sesleri nedeniyle olumsuz bağ kuran katılımcı sayısı ağırlıkta görünmektedir ve rahatsız olan katılımcıların hepsi, ürünü almak istemeyeceklerini belirtmiştir. Seyirlik deneyim adına fazla abartılı, yüksek ve mekanik bulunan sesler, tersi bir etki yaratarak, potansiyel müşterisini üründen uzaklaştırmıştır. Bu çıktılar, ASMR tekniğinin doğru kurgu ve anlatı koşullarında çalışacağının bir göstergesi olarak yorumlanmaktadır. Michelob Ultra içecek reklamı ve Sihua Dove çikolata reklamlarının bulguları ise tekniğin doğru kullanımı adına ortaya konulan argümanı desteklemektedir. Bu reklamlar dahilinde yaratılan atmosfer ve ASMR seslerinin kullanımı katılımcıların seyirlik deneyimlerinde yoğun bir olumsuz duruma neden olmamıştır. İçecek reklamı sonrası tüm katılımcılar görsel olarak kurulan manzara ve ürün ilişkisinin üzerlerinde olumlu bir etki yarattı̆̆ını söylemiş ve ürünü denemek isteyeceklerini vurgulamıştır. Çikolata reklamı ise özel olarak sinestezi etkisinin en fazla görüldüğü içerik olmuş; katılımcıların tamamı çikolata yemek deneyimi esnasında mutlu ve keyifli hissetmiştir. Bu noktada, yaşanan bu duyusal deneyim yoğunluğuna Lindstrom'un (2005) duyusal markalama yaklaşımı üzerinden bakmakta da yarar görülmektedir: Gülmez'e (2017, s. 62) göre, duyusal pazarlama, tüketicilerin yaşadığ1 deneyimleri ve duygularını süreç içinde bir araya getirmekte; bu bağlamda geleneksel yöntemlerin ayrı ayrı kullandığı koku, ses ve dokunma gibi duyusal uyaranları bir arada uygulama esasına dayalı bir pazarlama yaklaşımı sunmaktadır. Bu yolla hedeflenen, markanın tüketicisi üzerindeki etkisini arttırmak, tüketicide markaya dair bir sadakat yaratmayı başarmaktır.

“Duyular belleği etkileyebilmektedir çünkü potansiyel olarak tüketiciler içgüdülerine uyarak hareket etmeye meyillidir" (Molitor, 2017). Bu çerçevede Lindstrom (2005), beş duyunun mümkün olduğunca uyum içinde kullanılmasını ve bu durumun yarattığı uyumdan doğan başarının markaları hedef kitleleri ile çok daha yakın temasa geçirebilecek bir etkileşim ortamı sağladığını söylemekte; marka için duyusal anı üretilebilmesinin, marka ile tüketicisi arasındaki bağı kuvvetlendirdiğini ifade etmektedir. Duyusal marka deneyimi için aktarılan bu yaklaşımlar, daha teknolojik ve güncel bir düzeyde ASMR etkisinin neden yükselen bir trend olarak profesyonel reklam endüstrisi tarafından tercih edildiğini açıklar niteliktedir. 
Gerçekleştirilen bu araştırma ile ASMR'nin bilinçaltı düzeyde bir tetikleme ve uyarım yarattığ 1 ve bu etkinin otonom sempatik sinir sistemini doğrudan etkilediği görülmektedir. Duyusal bütünlük bağlamındaki etkileşim ağı yoğunlaştıkça, tüketicinin markaya olan sadakatinin artması ASMR'nin teknik olarak doğru çalıştığı iletişim kanallarında markalar için büyük bir marka-hedef kitle etkileşimi potansiyelini vadetmektedir. Ancak ASMR tekniğinin neden olabileceği potansiyel müşteri kaybı da araştırma dâhilinde gösterilmektedir. Bu bağlamda ASMR tekniği ile meydana getirilen bir reklam anlatısının, ana akım kanallara çıkmadan önce aynı konvansiyonel yaklaşımlarda olduğu gibi özellikle kendi hedef kitle segmenti üzerinde ölçümlenmesi önerilmektedir. Konvansiyonel reklam anlatısına göre, ASMR tekniği ile yaratılan potansiyel etkinin daha keskin olduğu düşünülmektedir. Bu bağlamda, yanlış çalışması muhtemel ASMR anlatısının tüketici etkileşimi de doğru orantılı olarak yanlış olacak ve ürünün pazar etkisi adına keskin olumsuz sonuçlar doğuracaktır.

Derinlemesine görüşmelerden elde edilen sonuçlara göre; katılımcılar sunulan 3 ASMR reklam filmini, diğer 2 ASMR içeriğine göre daha dikkatli takip etmiş ve içerikler bitince sorulan sorular bağlamında marka ve ürünlere ilişkin detaylı yorum ve bilgi vermiştir. Biyometrik sonuçlar da bu durumu desteklemektedir. Katılımcılar, ASMR reklam filmlerini, diğer içeriklere göre daha yüksek motivasyonel değerler ve nabız potansiyeli ile takip etmiştir. Aşağıda yer alan tablodan da okunabileceği gibi, Youtube ASMR içeriklerinin nabız değişimi ve deri iletkenlik seviyesi üzerindeki etkisi daha fazladır. Bu durum otonom düzeyde seyirlik deneyimin sonucunun rahatlama ve stres azaltma etkisine yöneliktir. Böylelikle reklam filmlerinin daha fazla motivasyonel uyarım ve dikkat ile takip edildiğini söylemek mümkündür. Aynı şekilde reklam filmlerindeki nabız etki farkının az olması da izleyicinin içerik ve anlatı ile etkileşime geçerek, Youtube içeriklerine göre daha dikkatli ve heyecanlı bir seyir deneyimi yaşadığını göstermektedir. Bu durum, ASMR tekniklerinin reklam izleyicisini yakalamak için önemli bir teknik yenilik olduğunu göstermenin yanı sıra, istenilen odağ 1 yakalamasına rağmen, izleyicisine kaygı ve stresten uzak bir seyirlik deneyim vadeden bir etkisinin olduğunu da ortaya koymaktadir. 
Tablo 5. ASMR Reklam İçeriği ile Normal İçeriğin Karşılaştırmasına Bir Örnek

\begin{tabular}{|l|c|c|}
\hline & Nabız Değişim Değeri (-) & SCL Değişim Değeri (-) \\
\hline Gentle Whispering Youtube İçeriği & $\mathbf{7 , 5}$ & 0,35 \\
\hline Sihua Dove Çikolata Reklam Filmi & $\mathbf{7 , 2}$ & 0,35 \\
\hline Michelob's Ultra Içecek Reklam Filmi & 5,3 & 0,19 \\
\hline Soap Coating Youtube İçeriği & 5,1 & $\mathbf{0 , 5 3}$ \\
\hline Safeguard Sabun Reklam Filmi & 4,8 & 0,47 \\
\hline
\end{tabular}

ASMR videolarının izleyicilerini rahatlatıp, sakinleştirmesini veya özellikle bazı durumlarda cinsel anlamda uyarmasının nedenini bir bakıma Jung'un kolektif bilinçdışı teorisi (Jung, 2003) üzerinden incelemek de mümkün görünmektedir. Bu bağlamda arketipler ${ }^{1}$ ile karşılaşan kullanıcılar, benlik kurulumlarını çok daha rahat tamamlamakta ve birçok farklı uyarana göre ASMR içerikleri ile daha rahat etkileşime geçebilmektedir. Kalıtımsal olarak gelen, hayatta kalmak için av olmama halinin pratiğindeki fısıltı, yavaş hareket, nesnelerin seslerine odaklanma gibi alışkanlıkların, kolektif bilinçdışı ile arketiplere dönüştürülerek aktarıldığı, ASMR ile de ortaya çıkmış olabileceği konusu, ASMR'ye dair farklı bir bakış açısını daha gündeme taşımaktadır. Bu bağlamda katılımcılardan bazılarının, içeriklerde yer alan kişisel dikkatin üzerlerine yoğunlaşması hissinin tanıdık geldiğini ve kendilerini iyi hissettirdiğini söylemeleri, tartışmanın bu bağlamda da sürdürülebileceğine bir işaret olarak görülmektedir. Katılımc1 1 (erkek, 32 yaş) Gentle Whispering Youtube içeriği esnasında, Maria'nın fısıltısının kendisinde genel bir uyku ve uyuşma hali yarattığını tanımlamakta; "küçükken gördü̈̆̈̈m anne şefkati ve annemin söylediği ninni gibi tanıdık" ifadesi ile tanımını arketip yaklaşımına uygun bir şekilde detaylandırmaktadır. Bir diğeri ise aynı bağlamda Maria'yı "90'larda televizyon reklamlarına çıkan tele-kızlar gibi tavrı" şeklinde yine bir arketip model üzerinden tasvir etmektedir (Katılımcı 6, kadın, 39 yaş).

\footnotetext{
1 "Arketip; algılarımızı örgütleyen, bilinç eylem ve içeriklerini düzenleyen bilinçaltına ait olgulardır. Jung'a göre, arketipler, kolektif bilinçaltının çekirdek yapıları olarak işlev görmektedir." Kolektif bilinçaltı ise kalıtımsal olarak nesiller boyu aktarılan ve günlük yaşamda farkında olmadan kararlarımızı etkileyen arketiplerin kontrolünde olan toplumsal ortak bellektir. Arketipler tüm iletişimsel ve kültürel kodlarda yer almakta ve kolektif bilinçaltını toplumsal düzeyde din, fantezi, folklor, rüya, edebiyat vb. kavramlar üzerinden idare etmektedir (Jung, 2003; Yüksel, 2013).
} 
Katılımcıların geçmişleri ve bilinçaltlarına yönelik kurulan bağlantılarda hem koruma, yakınlık, kişisel ilgi, rahatlama ve benzeri olumlu duygu durumları ortaya çıkmakta ve bu ortaya dökülen içsel dürtüler tanıdıklık üzerinden rahatlama getirmekte hem de benzeri bir şekilde cinsel uyarım durumları da somutlaşmaktadır. Kullanıcılar arketip ilişkisi kurdukları cinsel benzerlikler bağlamında ASMR içeriklerinden rahatsız olmakta ve uzaklaşmaktadır. Bu durum katılımcılardan birinin çikolata reklamını "aşırı erotik, her şeyden çok rahatsı oldum, asla bu ürünü almam" (Katılımcı 8, kadın, 40 yaş) gibi bir ifadesi ile çeşitli bağlamlarda kurulan içsel olanın dişa vurulma halinin, özellikle reklam içeriklerinde ASMR'nin bıçak sırtı bir teknik olması halini de gündeme getirmektedir.

Arketipler de aynı ASMR'nin tetiklediği biyolojik uyaranlar gibi, bilinçdışının birer ürünü halindedir. Toplumsal bilinçaltına ait olan arketipler ve benlik olguları, kişisel bilinçaltına doğru derinleştikçe komplekslere dönüşmekte (Jung, 2003); tam da bu noktada ASMR'nin rahatlatıcı ve yoğun ilgisinin devreye girip, kişisel bilinçaltındaki kompleks noktaları üzerinde olumlu etki yaratma gücüne sahip olduğunu tartışmak mümkün görünmektedir. Bu özelliğin iyi kurgulanması dâhilinde, ASMR tekniğinin hem rahatlatıcı anlatılar düzeyinde hem de profesyonel pazarlama ve satış düzlemleri özelinde olumlu duyusal etki yaratımını üst düzeyde yaşatacak bir araç olması hali gündemdedir. Bu durumun profesyonel reklam endüstrisi tarafından keşfedildiği görülmektedir. Ancak araştırmanın da ortaya çıkardığı gibi yanlış teknik ve anlatı kullanımı ASMR'nin aynı zamanda kuvvetli bir uzaklaştırıcı olarak da işlev görme halini ortaya koymaktadır. Bu nedenle araştırmanın bulgularından hareketle kurgu ve anlatının iyi tasarlanması ve özellikle ses etkileşimi düzeyinde düzeyin iyi ayarlanması önemli bir ticari gereklilik olarak görülmektedir.

\section{Sonuç}

ASMR tekniği ve etkileri üzerine gerçekleştirilen araştırmaların çoğu olumlu bulguları ortaya koymaktadır. Bu noktada ASMR tekniğinden etkilenen ve duyusal anlamda tetiklenen kullanıcıların hepsinin seyir deneyimleri sonunda hem daha rahat, sakin ve olumlu olduğu hem de farkındalık ve odaklanma düzeyinde daha yüksek potansiyelli çıtılar ortaya koydukları, bir önceki bölümde tartışılmıştır. 
ASMR'nin kronik ağrıları azaltma özelliğine dair bulgulanan verilerden hareketle hem fiziksel hem de psikolojik anlamda insanların hayatlarını iyileştirici etki yaratma adına bilimsel çalışmalar sürdürülmektedir. Konunun bu boyutu daha çok, tıp ve psikoloji çalışma alanlarını bağlarken, ASMR'nin duyusal anlamdaki yetkin etkisi ve yarattığı kuvvet marka iletişimi düzeyinde medya ve iletişim çalışmaları adına gelecek vadeden unsurlardan biri olarak gözlemlenmektedir. Bu çalışma ile ASMR'nin otonom sempatik sinir sistemi üzerindeki etkisi bir kez daha farklı bir karma metodoloji ile ortaya konulmuş, bu yönelim ile ASMR'nin profesyonel bir iletişim aracına dönüşmesi için gerekli olan gözlem ve bakış yaratılmaya çalışılmıştır. Bu aşamada, katılımcılar ile gerçekleştirilen derinlemesine görüşmelerden elde edilen derinlikli görüşler, biyometrik veriler ile birleştirilerek, özellikle akış dâhilinde bulunan ASMR reklam filmleri üzerinden dikkate değer bilgilere erişilmesini sağlamakta; hikâye anlatısı ve teknik düzeylerinde ise nelerden sakınılması gerektiğini ortaya koymaktadır.

İlerleyen çalışmalar adına, ASMR tekniğinin profesyonel medya içerik ürününe dönüştürülebilmesi ve parametrelerinin daha detaylı kontrol edilebilmesi için, çeşitli odak grup görüşmeleri ile farklı ASMR uyaranlarının içerik ve anlatı bağlamında test edilip, verilerin bulgulanması önerilmektedir. Bu noktada biyometrik veri tekniklerinin de sağladığı olanakların genişletilebilmesi adına, ASMR içerik ürünlerinin göz takip çalışmaları ile de desteklenmesi gerektiği düşünülmektedir. Medya ve iletişim çalışmaları bağlamında, ASMR etkisinin farklı habituslar düzeyindeki etkisi ve kültür iletişimine olan katkılarını da gözlemlemek mümkün görünmektedir. Tüm bu kurgu dâhilinde, gerçekleştirilen ASMR çalışmasının Türkçe literatürde medya ve iletişim çalışmaları adına bir ilk olma özelliği önemsenmekte ve ilerleyen çalışmalar için bakış açısı sağlamak adına zemin oluşturabileceği düşünülmektedir. 
EXTENDED ABSTRACT

\title{
Investigation of the Effect of Autonomous Sensory Meridian Response (ASMR) as a New YouTube Phenomenon in the Context of Audience and Content Interaction with Galvanic Skin Response (GSR) Measurement Technique*
}

\author{
Behiç Alp Aytekin \\ Aydin Adnan Menderes University
}

There are approximately 5.2 million autonomous sensory meridian response (ASMR) videos on YouTube which the world's most popular video sharing platform. Users watch ASMR videos for long hours and in series, and there are even individual ASMR YouTube channels consisting of such videos. The autonomous sensory meridian response (ASMR), was first described in 2010 as a concept. Jennifer Allen who defines the concept describes how the process developed in an interview with her (Richard, 2016). In order to name the feelings and physical outputs that she feels on her own and that she cannot identify, she explores the internet and makes headlines on various health blogs. However, although there are people who feel the same feeling and physical output as that, she cannot find a content that identifies the standard output with a name and unites it under a frame. In this context, she presents ASMR as a definition, and the definition is quickly adopted by the users to attract the masses that to discuss, produce and interact under the title, and thus engage the public agenda in the context of popularity. In this way, the name of a phenomenon that has both psychological and physical outputs is put forward as a non-clinical expression. After a name defines the concept, the widespread attention of users and the production of ASMR-based content increases, followed by the academic field dealing with ASMR (Copeland, 2017).

Within this framework, this type of content, which has increased its popularity on Youtube, is also on the rise in 2018 Google search trends around the world. The introduction of the Michelob Ultra brand to the 
world's most expensive mainstream advertising time zone with such a production technique is a remarkable point for the production of professional media content. In this context, even if the advertising has found strange and negatively criticized by its audience because of its first and new experience in social media since 28 January 2019, it has received 13 million views on YouTube; On Twitter, 4 thousand 200 times by making itself known about the brand has managed to create a communication traffic of up to 750 Tweets per minute (İçözü, 2019). This kind of consumerbrand, user-content interaction and spectator experience, unlike the content streams so far, promises a high-capacity yield on behalf of the media and communication work framework and the answer to what is popular content. When the question is coming up of why these contents are so accessible on YouTube, scientific researches revealing that ASMR videos have psychological outputs in most cases to reduce the anxiety levels of the users and to relieve the audience. The inclusion of ASMR content in the professional media content production ecosystem by opting out of the YouTube communication channel created the need to discuss the context of media and communication studies as well as the psychological dimensions and outcomes of the issue.

In this context, the selected content consisting of favorite ASMR videos on YouTube and produced advertisements with ASMR technique was presented to the participants $(\mathrm{n}=10)$. Electrodermal (GSR) and heart-volume (PPG) data were quantitatively collected from the participants. At the same time, quantitative outputs were supported with observation and indepth interview methods. The studies on the effect of ASMR on the brain and autonomic nervous system were performed by Smith et al. (2017) for the first time; however, such studies attempting to detect the effects on the autonomic nervous system have remained within a narrower scope. In the study of Smith et al. (2017), fMRI method was used from biometric data collection techniques to observe the domains of ASMR videos and the effect of contents on the default network status (DMN) of the brain was examined on 22 users. The findings of the study revealed the relationship between ASMR videos and the multiple states in which the brain rested and calmed itself. In an interview with Smith and his colleagues, Copeland (2017) reports that fMRI machines work very loudly, and techniques that measure brain waves, such as the EEG, contain many cables 
and sensors, which create distractions and situations that can hinder the relaxation effect. Therefore, although research has been conducted into a biometric data collection process similar to that of Smith et al. (2017), participants are referred to measure with a skin conductivity measurement (GSR) that is less disturbing technique during the procedure.

The results obtained from the study, as well as those who are relieved in terms of motivation from those who experience the contents, the presence of those who are disturbed in the direction of various variables have been observed. It has also been determined how these motivational changes provide communication and interaction output related to brand, product or service through the content shown. The fact that the results regarding the effects of ASMR contents in the media and communication studies literature have not been examined with such a mixed methodology is noteworthy as the original aspect of the research. It is thought that the results obtained from this research can be the basis of theoretical and practical studies which can be realized in the context of media and communication literature via ASMR contents.

\section{Kaynakça / References}

Banissy, M. J., Jonas, C. ve Cohen Kadosh, R. (2014). Synesthesia: An introduction. Frontiers in Psychology, 5, 1414 doi: 10.3389/fpsyg. 2014.01414

Barratt, E. L. ve Davis, N. J. (2015). Autonomous sensory meridian response (ASMR): A flow-like mental state. PeerJ- Life and Environment, 3(e851). https://doi.org/10.7717/peerj.851

Barratt, E. L., Spence, C. ve Davis, N. J. (2017). Sensory determinants of the autonomous sensory meridian response (ASMR): Understanding the triggers. PeerJ, 5, e3846.

BBC News Türkçe. (2019). Youtube'un Yeni Trendi ASMR. Erişim: 30 Ocak 2019, https://twitter.com/bbcturkce/status/109064222802-2779904

Boucsein, W. (2012). Electrodermal activity. Heidelberg: Springer.

Briggs, C. (1986). Learning how to ask: A sociolinguistic appraisal of the role of the interview in social science research. Cambridge: Cambridge University Press. 
Copeland, L. (2017). How researchers are beginning to gently probe the science behind ASMR. Erişim: 02 Aralık 2019, https://www.smithsonianmag.com/science-nature/researchers-begin-gently-probe-sciencebehind-asmr-180962550/

Dogtiev, A. (2019). YouTube revenue and usage statistics (2018). Erişim: 02 Kasım 2019, http://www.businessofapps.com/data/youtube-statistics/

Fredborg, B. K., Clark, J. M. ve Smith, S. D. (2018). Mindfulness and autonomous sensory meridian response (ASMR). PeerJ, 6, e5414.

Gibson, C. (2014). Gentlewhispering and ASMR: The voice that triggers euphoria and seven million youtube views. Erişim: 14 Şubat 2019, https://www.independent.co.uk/life-style/health-and-families/features/gentlewhispering-the-voice-that-triggers-euphoria-andseven-million-youtube-views-9929538.html

Gülmez, E. (2017). Marka tercihinde duyuların rolü: Starbucks ve Kahve Dünyası markalarının duyusal markalama açısından karşılaştırılması. Gümüşhane Üniversitesi İletişim Fakültesi Elektronik Dergisi, $5(1), 58-84$.

Haglage, A. (2018). Is ASMR the secret to treating anxiety and depression? Science is starting to think so. Erişim: 15 Şubat 2019, https://www.yahoo.com/lifestyle/asmr-secret-treating-anxiety-depression-science-starting-think-230528062.html

Hammill, G. (2005). Mixing and Managing Four Generations of Employees. FD Magazine Online, 12(2), http://fdu.edu/newspubs/-magazine/05ws/generations.htm

Hostler, T. (2018). ASMR videos could be a new digital therapy for mental health. Erişim: 15 Şubat 2019, https://theconversation.com/amp/mental-health-asmr-videos-could-be-a-new-digital-therapy100989?_twitter_impression=true

Howe, N. ve Strauss, W. (1992). Generations: The history of America's future 1584 to 2069. New York: Quill Publications.

İcil Tuncer, A. ve Tuncer, M. U. (2016). Eğlence reklamlarının viral uygulamaları ve $\mathrm{Z}$ kuşağı üzerinden bir değerlendirme. TRT Akademi Dergisi, 1(1), 210-229. 
İçözü, T. (2019). ASMR YouTube'dan sonra reklamlarda da öne çıkıyor. Erişim: 15 Şubat 2019, https://webrazzi.com/2019/02/04/asmr-youtubedan-sonra-reklamlarda-da-one-cikiyor/

iMotions. (2017). Galvanic skin response: The complete pocket guide. Denmark: iMotions.

Johnson, L. (2019). Millions of Americans just learned what ASMR is from Michelob Ultra's Super Bowl commercial - but they aren't loving it. Erişim: 02 Kasım 2019, https://www.businessinsider.com/michelobultras-asmr-super-bowl-commercial-2019-2019-2

Jung, C. G. (2003). Dört arketip. (Z. A. Yllmazer, çev.). İstanbul: Metis.

Lindstrom, M. (2005). Duyular ve marka. (Ü. Şensoy, çev.). İstanbul: Optimist Yayınları.

Maxouris, C. (2019). ASMR has been around for almost a decade, but you probably hadn't heard of it before this Super Bowl ad. Erişim: 02 Aralık 2019, https://edition.cnn.com/2019/02/04/us/asmr-super-bowltrnd/index.html

McDonnell, A. (2019). ASMR Goes Mainstream With Super Bowl Commercial. Erişim: 02 Aralık 2019, https://www.rollingstone.com/culture/culture-news/asmr-super-bowl-ad-zoe-kravitz-brain-orgasm789542/

Miller, J. (2015). Whispering on the internet is paying this woman's rent. Erişim: 02 Aralık 2019, https://www.cosmopolitan.com/-lifestyle/a40025/gentlewhispering-maria-internets-most-fascinating/

Molitor, D. (2017). The sensory potential. Erişim: 18 Şubat 2019, https://www.womanwise.com/2011/04/the-sensory-potential/

Poerio, G. L., Blakey, E., Hostler, T. J. ve Veltri, T. (2018). More than a feeling: Autonomous sensory meridian response (ASMR) is characterized by reliable changes in affect and physiology. PloS One, 13(6), e0196645.

Richard, C. (2016). Interview with Jennifer Allen, the woman who coined the term, "Autonomous Sensory Meridian Response" (ASMR). Erişim: 02 Aralık 2019, https://asmruniversity.com/2016/05/17/jennifer-alleninterview-coined-asmr/ 
Richard, C. (2017). Undergraduate student shares results of research project about ASMR and anxiety. Erişim: 16 Şubat 2019, https://asmruniversity.com/2017/07/01/stacey-watkins-asmr-research-anxiety/

Schröder, A., Vulink, N. ve Denys, D. (2013). Misophonia: diagnostic criteria for a new psychiatric disorder. PloS One, 8(1), e54706.

Shimmer, G. S. R. (2019). Shimmer GSR+ Unit. Erişim: 18 Şubat 2019, http://www.shimmersensing.com/products/shimmer3-wirelessgsr-sensor

Smith, S. D., Katherine Fredborg, B. ve Kornelsen, J. (2017). An examination of the default mode network in individuals with autonomous sensory meridian response (ASMR). Social Neuroscience, 12(4), 361365.

Social, W. A. (2018). Digital in 2018 in Western Asia Part. Erişim: 02 Kasım 2019, https://www.slideshare.net/wearesocial/digital-in-2018-inwestern-asia-part-1-northwest-86865983

Statista. (2019). Super Bowl average costs of a 30-second TV advertisement from 2002 to 2019 (in million U.S. dollars). Erişim: 02 Kasım 2019, https://www.statista.com/statistics/217134/total-advertisementrevenue-of-super-bowls/

Tran, K. (2017). Millennials still watch TV despite cord-cutting increases. Erişim: 02 Aralık 2019, https://www.businessinsider.com/millennials-still-watch-tv-despite-cord-cutting-increases-201711 ? $\mathrm{r}=\mathrm{UK} \& \mathrm{IR}=\mathrm{T}$

Trejos, A. (2017). Ice Bucket Challenge: 5 things you should know. Erişim: 02 Aralık 2019, https://www.usatoday.com/story/news/2017/07/03 /ice-bucket-challenge-5-things-you-should-know/448006001/

Trends, G. (2019). Google Trends ASMR Sorgusu. Erişim: 02 Kasım 2019, https://trends.google.com.tr/trends/explore?q=asmr

Young, J. ve Blansert, I. (2015). İdiot's Guide As Easy As It Gets: ASMR. New York: Penguin Random House.

Yüksel, C. (2013). Carl Jung, kolektif bilinçaltı ve arketipler. Erişim: 18 Şubat 2019, https://www.slideshare.net/canyuksel/carl-jung-kolektif-bilinalt-ve-arketipler 


\section{Kaynakça Bilgisi / Citation Information}

Aytekin, B. A. (2019). İzleyici ve içerik etkileşimi bağlamında yeni bir You Tube fenomeni olarak otonom duyusal meridyen tepki (ASMR) etkisinin deri iletkenliği ölçümü (GSR) tekniği ile incelenmesi. OPUS-Uluslararası Toplum Araştırmaları Dergisi, 10(17), 1568-1600. DOI: 10.26466/opus.533789 